\title{
INFORMATION SYSTEMS DESIGN FOR EARLY CHILDHOOD EDUCATION SERVICES
}

\author{
M Fitriawati1*, R H Lestari2 \\ ${ }^{1}$ Universitas Komputer Indonesia, Indonesia \\ 2 IKIP SILIWANGI \\ *Corresponding Author:miafitriawati@gmail.com
}

\begin{abstract}
Parents are working harder due to the increased needs of necessities of life. This causes mothers to do so that they meet these necessities. As a result, mothers leave their children aged 2 (two) to 4 (four) years in the playgroup. However, children's development is often out of hand because it is not adequately recorded. Recording children's development manually has several weaknesses; one is the damaged children's development recording book. Based on this problem, this research aims to develop information systems design for early childhood education services to monitor children's development. The method used was SDLC. The result of the research is the information system as children development monitors in early childhood education services and tools for teachers in managing the information regarding children's growth and development effectively and efficiently.
\end{abstract}

Keywords: Information System, SDLC method, System design

JTIP@Attribution-ShareAlike 4.0 International License

\section{INTRODUCTION}

Life needs that increase with economic demands, social status, and lifestyle make most mothers choose to work outside the home. On the other hand, many cases are associated with caregivers who cannot be trusted, wrong upbringing when parents are not home, and the other cases where mainly social assistance is recognized as essential needs for parents of toddlers. The period of transition to parenthood is a challenging time where enduring stress, financial adjustments, an upheaval of life, new responsibility, and sleep deprivation are started to come [1][13]. Such conditions make working mothers inevitably leave their children in childcare services, a playgroup. A playgroup is a form of early childhood education unit for non-formal education that organizes educational programs for children aged 2 to 6 years with a priority of ages 3 and 4 years. Nonformal education has implications for policymakers, as this is a model that has the potential to build capacity in disadvantaged communities and provide educational experiences for preschool children [2][12].

In general, this playgroup becomes an alternative for working mothers to leave their children, where children who are entrusted will be given lessons and games. Every activity of children will always be monitored and assessed with stages that are adjusted to the age of the child. One form of obligation from Kelompok Bermain (KOBER) as playgroups is to provide reports on children's activities as well as growth and development and problems that occur (if any). The problem that arises is that most KOBER still does daily records from the semester program planning to the processing of assessment of children's learning processes and results carried out by the teachers at KOBER, which are still written in the book as needed, and then recorded again in each report book. Children who will later be given to parents who entrust their children to KOBER. Several countries have put their concern on the importance of early childhood education. Preschool teachers, as the facilitator, are expected to use information communication technology (ICT) to plan and provide the learning material for children [3]. Information Technology, or commonly known with IT, means electronic and digital media such as computers, cameras, e-book readers, and Internet [4]. The use of ICT in education has an impact on new educational environments, providing new teaching methods, changing the traditional teacherstudent relationship, and improving education quality [5][14]. This is an effective way to develop 
ICT specialist's skills in meeting the demand of modern information society [6]. According to the results of research conducted by Liu, Toki \& Pange, kindergarten teachers in Greece have been utilizing ICT in preparing tools and teaching materials. Another research conducted by Kara \& Cagiltay says that playgroup curriculum has included technology so that teachers can use ICT [7]. Therefore, by looking at the references above, it can be concluded that the development of ICT can be used by parties related to early childhood services in playgroups in managing their information.

Therefore, this study aims to assist educational services in early childhood in playgroups that require a computer-based information system design where the system itself is made on a website-based basis. The information system design for first childhood education services used the System Development Life Cycle (SDLC) method to develop the system where this development method has advantages in system design.

\section{METHOD}

The design in this study used the SDLC (System Development Life Cycle) method at the development stage. Planning and analysis were done by collecting data through technical use of organizing playgroups, and samples of data and document processing results can be obtained from several KOBER. Software Development Life Cycle is a well-defined and systematic approach, practiced for the development of a reliable, high-quality software system [8]. The software development life cycle or SDLC, for short, is a methodology for designing, building, and maintaining information and industrial systems [9]. Similarly, SDLC models are used to develop software projects with different development phases, namely analysis phase, designing phase, programming phase, testing phase, and maintenance phase [8]. In specific terms relevant to SDLC, since SDLC or Systems Development Life Cycle is a cyclical methodology, steps repeat so that changes can be made to the design in the next cycle [10]. Based on these references, it can be said that the SDLC method can help the writer in designing information systems for early childhood education services in playgroups effectively and efficiently.

\section{RESULTS AND DISCUSSION}

This study used the stages in the SDLC method, where this method has the advantage that is the System Development Life Cycle (SDLC) can be defined as the formal process of developing information systems through successive stages or phases [11]. The results obtained in the analysis process, researchers found that problems that often arise in the process of early childhood services in playgroup are recording daily observations of children's activities, measuring physical growth and development, scheduling children's activities, special needs regarding each activity, growth and development reports. Therefore, several features are needed, including components for teachers and parents. On the display features for teachers regarding curriculum, they were learning planning, schedules, assessment of child development in reports, educators and education staff, facilities, and infrastructure. While in terms of parents, there is a feature to see the schedule of children's activities, reports on child development, and facilities to ask questions or provide feedback about the needs or problems faced by children entrusted. Following in Figure 1 is the design of the database that will be used in the information system design for early childhood services in KOBER.

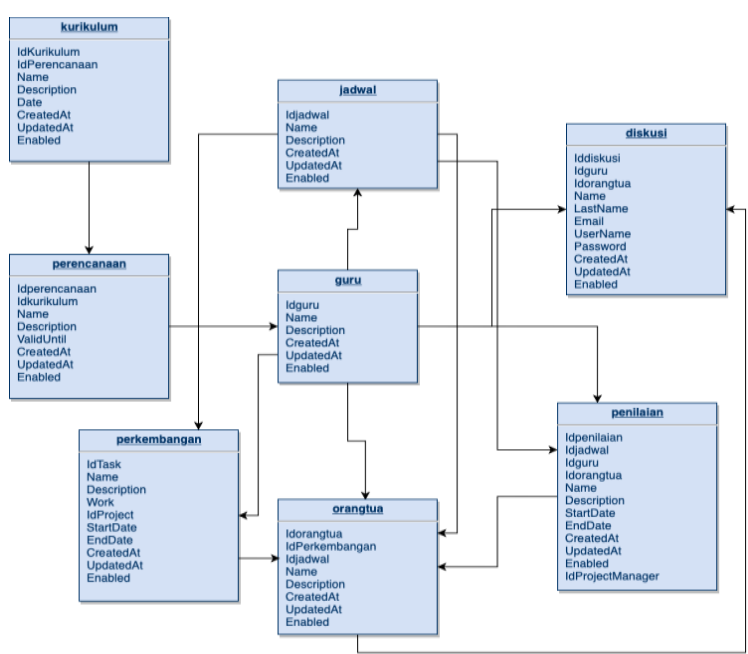

Figure 1. The database information system design

Figures 2, 3, 4, and 5 are the information system design for early childhood education in playgroup. The system designed was named SiKOBER (playgroup information system), made on a website-based basis. 


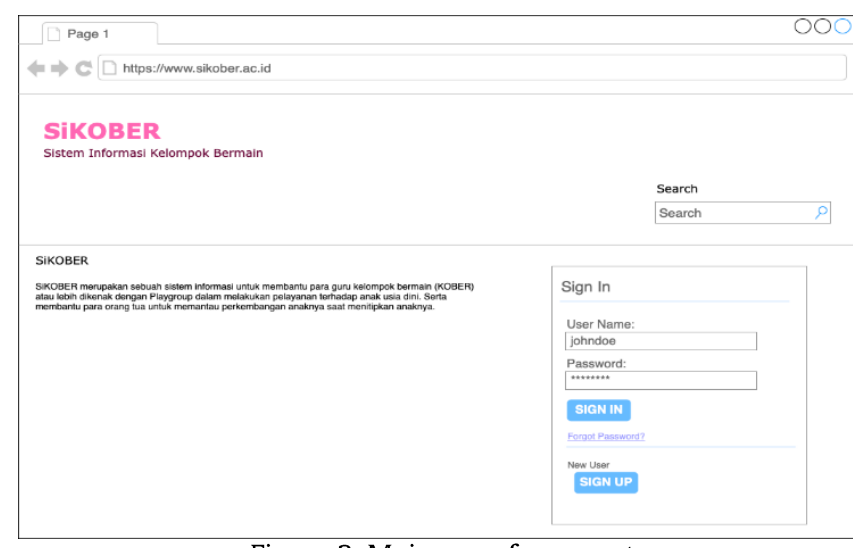

Figure 2. Main page for parents

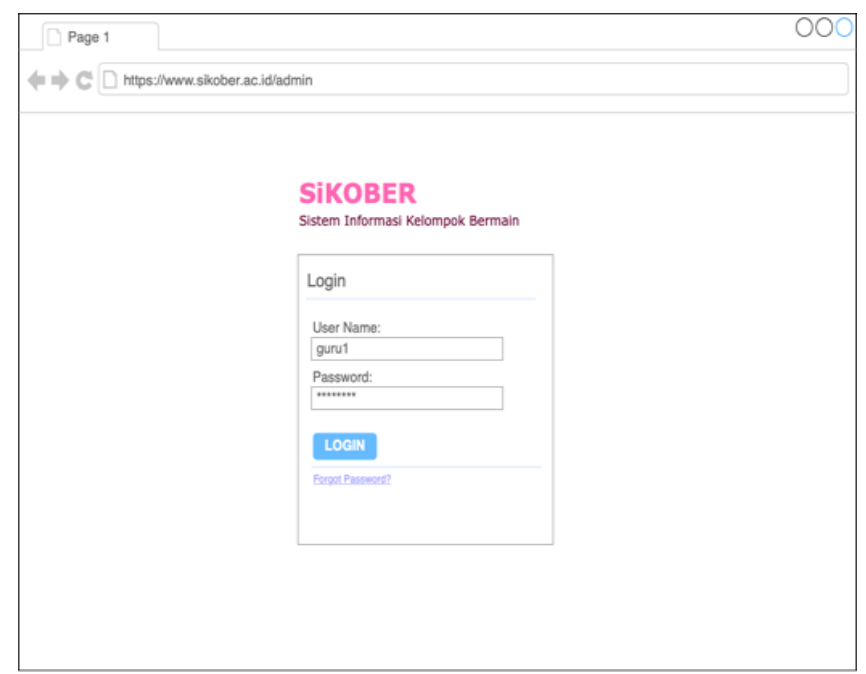

Figure 3. Main page for teacher

Figure 2 and Figure 3 are the main display design for teachers and parents consisting of facilities for signing in by parents and logging in for teachers. This display design is intended to enter into the home display in figure 4 and figure 5. In figure 2 illustrates the structure of the main look design for parents. This central view describes how the playgroup profile and parents can sign if they already have an account that has previously been given by the teachers to be able to see the home page in figure 5 . While in figure 3 here explains about teachers who have to login first to be able to enter the system. Existing facilities other than to sign in by parents, there is a facility to view profiles and activities carried out by playgroups.

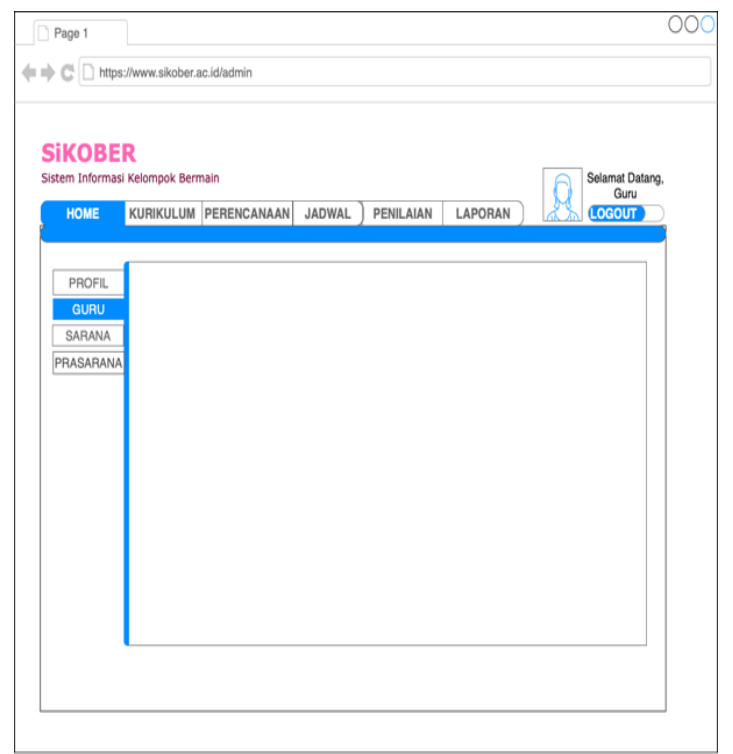

Figure 4. Home page for teacher

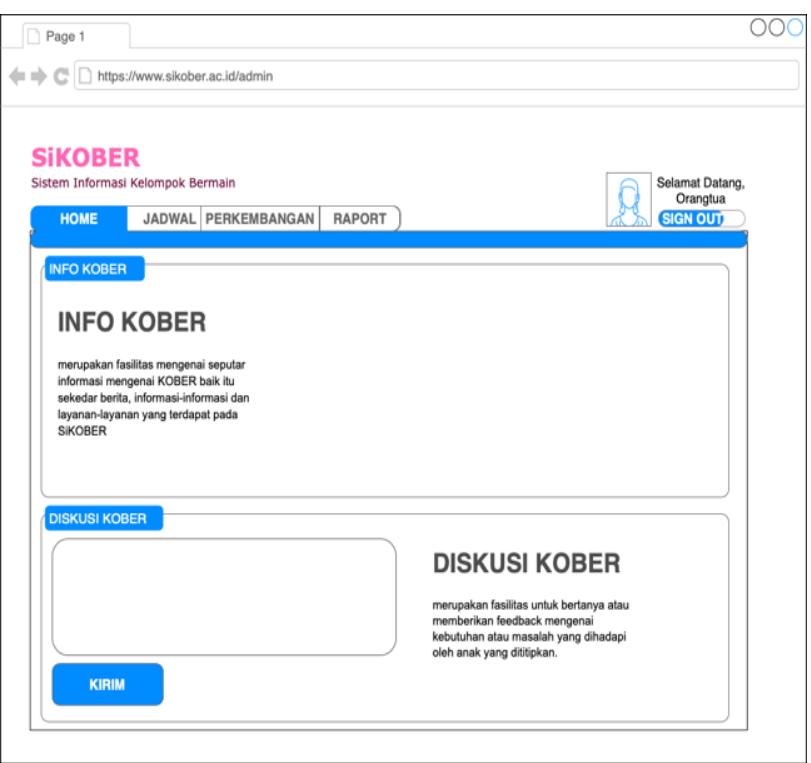

Figure 5. Home page for parents

While in Figure 4 and Figure 5 are figures of the home display for parents and teachers. The appearance on the home page for teachers and parents is different because it adjusts to their respective facilities. Existing facilities on the home display in figure 4 include facilities for viewing schedules, developments, and report cards on the parent's side. In contrast, on the teacher's side as a part of the playgroup, there are curriculum, planning, schedule, assessment, and report facilities in figure 5 . The design of the design in figure 4 has the aim of doing all the activities that take place in a playgroup filled by teachers to be then seen by the parents who put their children in the playgroup. While figure 5 is a page for parents to see how their 
child is progressing during the nursery directly. This design is made in general by adjusting the needs required by the teachers of the playing group. So it can be used by any playing group.

\section{CONCLUSION}

The conclusion that the writers can take is that the design of this information system can help the programmer in making the information system, then it can be implemented. The method of this information system can be developed into analytical tools on how the child's growth and development by looking at assessments in children's daily activities by using unique methods to produce evaluations related to the development of children according to their age.

\section{REFERENCES}

[1] Hancock, K. J., Cunningham, N. K., Lawrence, D., Zarb, D., \& Zubrick, S. R., 2015. Playgroup participation and social support outcomes for mothers of young children: A longitudinal cohort study PLoS ONE 10(7) pp. 1-15

[2] Nyland, B., Nyland, C., Gao, Y., Ng, J., \& Zeng, X. 2016. The Si Huan Playgroup: an initiative to provide non-formal early childhood education experiences to children of migrants in Beijing Asia Pacific Journal of Education 36(3) pp. 319-331

[3] Fitriawati, M., \& Lestari, R. H. 2019, Design of the Information System for Kindergarten Learning Evaluation used Kanban Methodology IOP Conference Series: Materials Science and Engineering 662(2) pp. 022025

[4] Saxena, A., \& Hew, K. F. T., 2016. Using ICT in Early Childhood: What Teachers, Principals, and Parents Say 24th International Conference on Computers in Education 24, pp. 511-520

[5] Tezci, E., 2009. Teachers' effect on ICT use in education: the Turkey sample Procedia Social and Behavioral Science 1 pp. 1285-1294

[6] Tondeur, J., Van Braak, J., \& Valcke, M. 2007 Curricula and the use of ICT into the education: two worlds apart? British Journal of Educational Technology 38(6) pp. 962-976

[7] Kara, N., \& Cagiltay, K. 2017. In-service preschool teachers' thoughts about technology and technology use in early educational settings Contemporary Educational Technology 8(2) pp. 119-14.
[8] Rastogi, V. 2015 Software Development Life Cycle Models- Comparison, Consequences International Journal of Computer Science and Information Technologies 6(1) pp. 168-172

[9] Karambir, S, T. 2015 A Simulation Model for the Spiral Software Development Life Cycle International Journal of Innovative Research in Computer and Communication Engineering 3(5), pp. 3823-3830.

[10] Otero, A, R. 2018 System Development Life Cycle In Information Technology Control and Audit Auerbach Publications pp. 201-236

[11] Scroggins, R. 2014 SDLC and Development Methodologies Global Journal of Computer Science and Technology: C Software \& Data Engineering 14(7) pp. 1-6

[12] Dony Novaliendry, Supratman Zakir, Yeka Hendriyani, Titi Sriwahyuni, Resmi Darni 2020. English Game Education Application with Mobile Learning for Childhood. International Journal of Advanced Science and Technology. 29, 06 (Apr. 2020), 1862 - 1868.

[13] D. Novaliendry, Y.Hendriyani, C-H.Yang, \& H. Hamimi, 2015, The Optimized K-Means Clustering Algorithms to Analyezed the Budget Revenue Expenditure in Padang. Proceeding of International Conference on Electrical Engineering, Computer Science and Informatics, 61-64.

[14] A. Samala, B. Fajri, F. Ranuharja, and R. Darni, "PEMBELAJARAN BLENDED LEARNING BAGI GENERASI Z DI PERGURUAN TINGGI (STUDI KASUS: PENDIDIKAN TEKNIK INFORMATIKA UNIVERSITAS NEGERI PADANG)", tip, vol. 13, no. 1, pp. 45-53, Mar. 2020. 